and of documents, prints and books. The undertaking and encouragement of research into all historical aspects of the subject. The stimulation of research into the best ways of using leather, into possible new uses and into the production of new and special types of leather. The preservation and encouragement of high standards of craftsmanship and design". During the preparatory period, the Museum staged a comprehensive exhibition entitled "Leathercraft through the Ages", planned by Dr. C. H. Spiers and Mr. J. W. Waterer and shown at many provincial centres as well as in London.

Brotherton Collection of the University of Leeds: Annual Report for 1950-51

ThE sixteenth annual report of the Brotherton Collection Committee of the University of Leeds covers the session 1950-51 (pp. 9 ; University, 1951) and records the virtual completion of the cataloguing of those books in the English literature section which had not been incorporated in the new catalogue. A start has been made on cataloguing the Romany Collection. On June 30, 1951, the Brotherton Collection contained some 23,726 books, 15,927 pamphlets, 585 manuscripts, 4,106 deeds, 31,555 letters and 25 maps. The first main exhibition of the session consisted of books, manuscripts and other items from the Romany Collection presented earlier in the year by Mrs. McGrigor Phillips. The second exhibition, of English grammars and dictionaries, designed to illustrate their development frem the seventeenth to the nineteenth centuries, drew upon the resources of the whole University library, and a third exhibition of books and other documents of 1851 was planned to illustrate the life, thought and literature of a century ago. Some thirty organized parties were included among the yearly total of more than a thousand visitors to the Collection, and the report includes some details of items presented during the year.

\section{Breeding Biology of the Spotted Flycatcher}

Using data on the breeding biology of the spotted flycatcher which he had obtained from observations carried out by different investigators at 548 nests, D. Summers-Smith has shown that the normal laying period for this bird in Britain extends from mid-May until the end of July, a small number of birds being double-brooded (British Birds, 45, No. 5, May 1952). The average clutch-size decreases from about 4.5 eggs at the end of May to less than 3 eggs by the end of July. A slightly, but significantly, higher average clutch-size occurs in north England and Scotland than in the rest of England and Wales throughout the breeding season. It is probable that the spotted flycatcher can only successfully rear a brood of five young in Britain when the conditions are very favourable. Summers-Smith also reports that no significant variation in nesting success with season has been detected. The average incubation period is $13 \cdot 2$ days and the nestling period $13 \cdot 4$ days.

An Alternative to Regular Clear-Felling in Forestry

UP to the outbreak of the First World War, at which period the bulk of the woods in Great Britain were on private estates, the general forestry method in force was clear-felling and replanting chiefly with conifers. The true practice of sylviculture and correct forest management, as found in Western Europe and enforced by trained British forest officers in India and a fow other parts of the British
Empire, was at that time little understood in Britain beyond clear-felling and planting and coppice woods. In a recent issue of Scottish Forestry $(6$, No. 1 ; 1952), the journal of the Scottish Forestry Society, an article appears entitled "The Alternative to Extensive Regular Clear-Felling", by M. J. Penistan, which shows a considerable departure in practice on a large estate in the south of Scotland. On this estate the management recently decided to limit very extensively the existing policy of clear-felling and replanting, especially in the old hardwood areas. As a result of this decision, an interesting situation arose both from the point of view of instructing the forestry staff and securing enough timber to maintain the estate sawmills - a position which has often faced the trained forest officer overseas in the past over far larger areas than the 650 acres maintained by Mr. Penistan. The difficulties in the management were the outcome of the fellings of the two World Wars. The new treatment is described as mixed forestry, and four so-called new rules are drawn up on sound premises for the existing conditions of the crops : to obtain on every acre a continuous yield of the largest volume of timber; to cut only such timber as is ripe and suitable for conversion; to get rid of all uneconomic growth at an early stage in life and to introduce trees of high quality by natural seed or planting; and to secure conditions for adequate recruitment of timber, that is, enough from which to select fine poles to grow to timber. For a private estate the proposed management is a great departure in forestry practice in Great Britain. Mr. Penistan says that his article, showing how this is to be carried out, has been compiled from the notes made after discussions of the necessary steps to be taken. It is a pity that these notes are not reproduced in a rather more lucid form. To the forester who has been in charge of forest areas managed on professional technical lines they will be understandable; but it may be suggested that some rearrangement would appear to be advisable for those who, though they have not had this experience, may wish to follow Mr. Penistan's admirable departure.

Leicester Museum and Art Gallery: New Bulletin

Lemcester Museum and Art Gallery is to be congratulated on the issue of the first number of a Bulletin. It is envisaged that each number shall be a coherent whole, and that all articles shall be linked by some common and fundamental idea. 'The present theme is "Origin", and the second will be "Growth". Regular publication is not promised ; but future issues will appear as the necessary material is forthcoming. Following a general editorial article, several examples of origin are discussed. These are arranged in order of their natural development, the earth, the animal, the artefact, recorded knowledge, and art. T'he first paper thus describes igneous intrusions in the county of Leicester and is followed by a description of the pentadactyl limb and the changes it has undergone in mammalian evolution. An archæologist then stresses, with illustrative examples, the importance of origin; knowledge is represented by a paper on the early history of the Town Library, and art by a discussion of a drawing of two horsemen by Sir James Steuart.

\section{Reporting Research in Education}

IN the second pamphlet published by the University of Manchester School of Education (Manchester Univ. Press. Pp. viit 24. 3s. 6d. net), Stephen Wiseman 